International Research Journal of Management, IT \& Social Sciences
Available online at https://sloap.org/journals/index.php/irjmis/
Vol. 6 No. 6, November 2019, pages: 188 193
ISSN: 2395-7492
https://doi.org/10.21744/irjmis.v6n6.790

\title{
Effect of Use of Regional Financial Management Information Systems on Individual Performance in BPKAD Sikka Regency
}

\author{
Wihelmina Maryetha Yulia Jaeng a \\ I Made Sadha Suardikha ${ }^{b}$ \\ I. G. A. N. Budiasih ${ }^{\mathrm{c}}$
}

Article history:

Received: 27 July 2019

Accepted: 30 September 2019

Published: 05 November 2019

\section{Keywords:}

individual performance; information quality; quality of collaboration; system quality; use of SIPKD;

\begin{abstract}
The Regional Financial Management Information System (SIPKD) is an integrated application that is used as a tool for the Regional Financial and Asset Management Agency of Sikka Regency in carrying out financial management activities so that it is able to produce financial reports of the local government. Testing the measurement of SIPKD success using the DeLone and McLean (2003) models. This study examines the effect of collaboration quality, information quality, system quality on the use of SIPKD and the effect of using SIPKD on individual quality. The sampling technique uses purposive sampling with criteria for all SIPKD users in BPKAD Sikka Regency, as many as 51 people. Data collection using a questionnaire distributed to BPKAD Sikka Regency. Data analysis using Partial Least Square 3.2.8. The results showed that the quality of collaboration, information quality, system quality has a positive effect on the use of SIPKD. The use of SIPKD has a positive effect on individual performance.
\end{abstract}

2395-7492@ Copyright 2019. The Author. This is an open-access article under the CC BY-SA license (https://creativecommons.org/licenses/by-sa/4.0/) All rights reserved.

\section{Author correspondence:}

Wihelmina Maryetha Yulia Jaeng,

Udayana University, Denpasar, Indonesia.

Email address: wihelminajaeng@gmail.com

\section{Introduction}

The presence of Information Technology (IT) in the last few decades has proven that IT is able to provide something that was initially difficult to be easily done or managed by the administration, namely in its speed and accuracy. The government is spurring the speed of improving the quality of the State Civil Apparatus (ASN) for the formation of the Smart ASN generation for the realization of world-class bureaucracy. This generation is also expected to anticipate the challenges of disruption in the industrial revolution era 4.0. Bureaucracy digitalization will create increasingly optimal, efficient and fast public services. The challenges and obstacles faced by ASN serve as strengths and opportunities to

${ }^{a}$ Udayana University, Denpasar, Indonesia

${ }^{\mathrm{b}}$ Udayana University, Denpasar, Indonesia

${ }^{\mathrm{c}}$ Udayana University, Denpasar, Indonesia 
encourage the vision of Indonesia in 2045, with a foundation on the transformation of bureaucratic digitalization that makes access to services to the public easier. (PR MenPANRB, 2019).

Guided by Government Regulation No. 56 of 2005 concerning Regional Financial Information Systems, the Government of Sikka Regency since 2012 has implemented the Regional Financial Management Information System (SIPKD). Sikka District Government Financial Report obtained a Fair Opinion without Exception for three consecutive years from 2016 to 2018, this shows success in the implementation of SIPKD. The information system success model DeLone \& McLean (2003), as a measure to determine the success rate of an information system that has six variables, namely information quality, system quality, service quality, interest in using as an alternative to usage, net benefits. The success of an information system depends on how the system is run, the ease of the system for its users and the usefulness of the technology used.

Research on Assessing enterprise wiki success from the perspective of end-users: an empirical approach, Behavior \& Information Technology by Bhatti et al., (2018). This study conducted an empirical investigation of 177 end users of corporate wikis to evaluate the perceived performance after the use of the wiki. The perceived performance of endusers of wikis companies is evaluated by measuring the efficiency, effectiveness, and capacity development felt by users. The findings show that the quality of collaboration, the quality of information and the quality of the company's wiki system help users in terms of increasing efficiency, effectiveness and capacity development. Tan et al., (2015), used seven variables in his research, namely system quality, information quality, service quality, system use, user satisfaction, individual performance, and organizational performance. The results of his study stated that of the nine hypotheses tested, only four were accepted. The hypothesis that was received and had a significant positive effect was the effect of system quality on usage, the effect of the use of individual performance, the effect of user satisfaction on individual performance, and the effect of individual performance on organizational performance. While five other hypotheses are rejected.

This study aims to determine the effect of collaboration quality, information quality, system quality on the use of SIPKD, and the effect of using SIPKD on individual performance. The quality of collaboration provided by SIPKD provides convenience and comfort in communicating with colleagues, supports effective and efficient information sharing and document storage and sharing. DeLone \& McLean (2003), explain that the higher the quality of the system and the optimal use of the system, the user will feel satisfied. The better the quality of information (output) generated from the system, the more user satisfaction will be the use of the system because it can complete its work. The use of information systems that have been developed refers to how often users use information systems. The more often users use information systems, usually followed by the more levels of learning (degree of learning) that users get about information systems.

\section{Literature review and hypothesis}

Theory of Reasoned Action (TRA) is a general behavior model developed by Fishbein \& Ajzen, 1975 (McCoy et al., 2007 and Hartono, 2007). The TRA model can be applied because the decision made by an individual to accept an SI technology is a conscious action that can be explained and predicted by their behavioral interests (Hartono, 2007; Arauz et al., 2016). The DeLone \& McLean (1992), model consists of six main variables to measure the success of a system, namely system quality, information quality, usage, user satisfaction, individual impact, and organizational impact. While the DeLone \& McLean (2003), Model adds service quality variables to the model and combines individual and organizational impact variables into net benefits. Regional Financial Management Information System (SIPKD) is an integrated application that is used as a tool for regional governments that is used to improve the effectiveness of the implementation of various regulations in the area of regional financial management based on the principles of efficiency, economics, effective, transparent, accountable and auditable (SIPKD Implementation Guidelines, 2010, Ministry of Home Affairs: Jakarta).

He \& Yang (2016), stated that collaborative tasks differ from tasks collected because they require a high degree of dependency and different information needs for group collaboration. Information quality is the output produced by the information system used (DeLone \& McLean, 1992). The quality of information systems means that how well the ability of hardware and software to produce information to meet the needs of information users (DeLone \& McLean, 2003). The use of information systems is a person's behavior when using information systems (Jogiyanto, 2007; Dewi et al., 2018). Performance is the performance carried out by an organization within a certain period of time which refers to the achievement of the vision, mission, goals, and objectives based on the organization's strategic plan (Pratolo \& Jatmiko, 2017).

Jaeng, W. M. Y., Suardikha, I. M. S., \& Budiasih, I. G. A. N. (2019). Effect of use of regional financial management information systems on individual performance in BPKAD Sikka Regency. International Research Journal of Management, IT and Social Sciences, 6(6), 188-193. https://doi.org/10.21744/irjmis.v6n6.790 
Collaboration involves synchronized efforts from team members to solve a given problem or achieve a common goal (He \& Yang, 2016). Research conducted by Bhatti, et al 2018, states that the quality of collaboration is significant in the use of wiki systems. From the statement above, it can be concluded that the higher the quality of collaboration, the greater its use. In addition, if the user considers SIPKD to provide high-quality collaborative features, it will provide benefits and help users do work more effectively and efficiently. According to the explanation, the first hypothesis that can be developed are:

H1: The quality of collaboration has a positive effect on the use of SIPKD

Theory of Reasoned Action is prepared using the basic assumption that humans behave in a conscious manner and consider all available information. Information quality is the perception of users about how can an accounting software is able to show and convey the intended message, the quality of information is the output produced by the information system used (DeLone \& McLean, 1992). Research conducted by Salim (2014), states that a positive and significant relationship between information quality and usage. This research was also conducted by Yasa \& Ariyanto (2017). There was a significant influence between the information quality variables on the use of the system. From the statement above, it can be concluded that if the quality of information as the output of a system is very good, it will be increasingly able to attract users to use the system, the use of the system here is very dependent on the quality of a system itself. If users of information systems believe that the quality of information produced from the system used is good, they will use the system. According to the explanation, the second hypothesis that can be developed are:

H2: Information quality has a positive effect on the use of SIPKD

Theory of Reasoned Action can be applied because the decision made by an individual to accept an SI technology is a conscious action that can be explained and predicted by their behavioral interest (Hartono, 2007). The quality of the system means the quality of the combination of hardware and software in the information system. The focus is on the performance of the system, which refers to how well the capabilities of the hardware, software, policies, procedures of the information system can provide information on user needs (Salim, 2014). Research conducted by Salim (2014); Tan et al., (2015); Hudin \& Riana (2016), state that there is a positive and significant relationship between system quality variables and usage. From the above statement it can be concluded that the better the quality of a system, it will lead to increased use of the system. The quality of information systems usually focuses on the characteristics of system performance. If the information system user believes that the quality of the information system of the system used is good, then the user of the information system will improve. So the system is said to be successful if, the quality of the system produced by the system can provide useful information and can increase the use of information systems. According to the explanation, the third hypothesis that can be developed are:

H3: The quality of the system has a positive effect on the use of SIPKD

The theory of reasoned action is a theory that explains that actions that are influenced by one's reaction and perception of something will determine the person's attitude and behavior. The use of an information system can have a positive impact on individual performance. Research Tan et al., (2015); Yasa \& Ariyanto (2017), found an influence between the use of the system and individual performance. This research was also conducted by Kesumman \& Suardikha (2016), stating that the use of information systems has a positive effect on employee performance. From the above statement, it can be concluded that individual performance will improve if accompanied by the use of information systems, which are able to accelerate in completing work. According to the explanation, the fourth hypothesis that can be developed are:

H4: The use of SIPKD has a positive effect on individual performance.

\section{Materials and Methods}

The population in this study is the Head of the Agency, Secretariat, Budget, Treasury, Accounting, Asset, Functional Group, and SIPKD Operators. The object of research is the Regional Financial and Asset Management Agency (BPKAD) of Sikka Regency which is located at Kartini Street, No.26, Beru Village, East Alok District, Sikka Regency, NTT. The sample collection technique in this study was purposive sampling. The type of data used in this research is qualitative data which is quantitative. Qualitative data includes answers to the statements contained in the questionnaire. Sources of data in this study are primary data obtained from respondents through questionnaires and 
researcher interviews with informants. The data analysis method used in this study is Partial Least Square3.2.8. The main purpose of the Partial Least Square method is to predict.

\section{Results and Discussions}

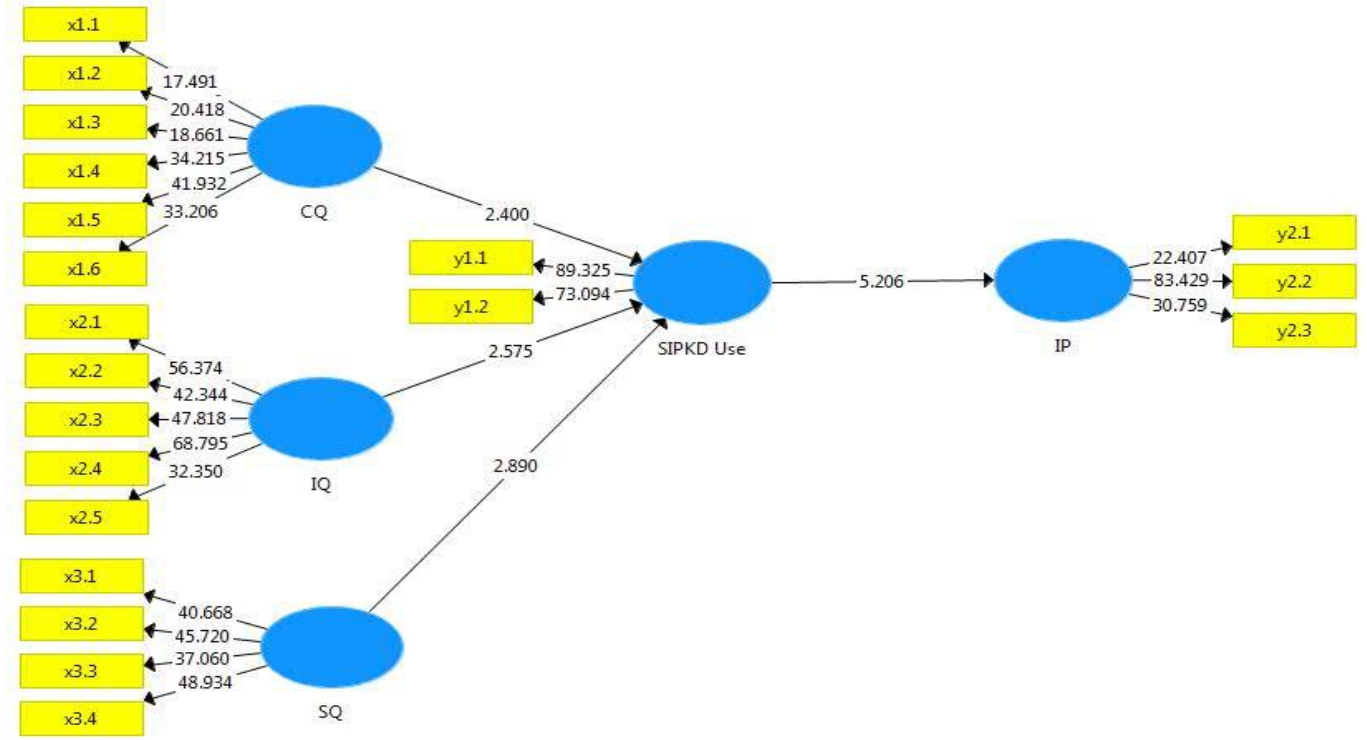

Figure 1. Bootstrapping research variables

\subsection{Effects of Collaborative Quality on the SIPKD Use}

The results show that the quality of collaboration has a positive effect on the use of SIPKD in BPKAD Sikka Regency, so the first hypothesis (H1) is accepted. The influence of the quality of collaboration on the use of SIPKD in BPKAD Sikka Regency can improve the efficiency and effectiveness of users, ease and comfort in communicating with colleagues. The higher the quality of collaboration, the greater the use, because if the user considers SIPKD to provide high-quality collaborative features, it will provide benefits in doing work. The results of this study are in line with the research of Bhatti et al., (2018), Assessing enterprise wiki success from the perspective of end-users: an empirical approach, Behavior \& Information Technology. The results of his research show that the quality of collaboration has a significant indirect effect on individual performance through the use of wikis and wiki user satisfaction.

\subsection{Effect of Information Quality on SIPKD Use}

The results show that information quality has a positive effect on the use of SIPKD in BPKAD Sikka Regency so that the second hypothesis (H2) is accepted. The use of SIPKD in BPKAD in Sikka Regency has facilitated and accelerated regional governments in the preparation of the budget, administration and financial reporting/accountability. The good quality of information is reflected in the usefulness of the output produced by SIPKD, because the more often users use SIPKD, the more level of learning the user gets about SIPKD. Quality information generated from the use of SIPKD is a solution in order to improve regional financial accountability.

This research was also conducted by Yasa \& Ariyanto (2017), an analysis of the success of the Regional Management Information System by adopting the DeLone \& McLean model. The results of his study indicate that the quality of information influences the use of SIMDA.

The results of this study support the Theory of Reasoned Action which proves using the basic assumption that humans behave in a conscious manner and consider all available information. Whereas the DeLone and McLean models prove that the output produced by SIPKD can assist users in completing the given task.

Jaeng, W. M. Y., Suardikha, I. M. S., \& Budiasih, I. G. A. N. (2019). Effect of use of regional financial management information systems on individual performance in BPKAD Sikka Regency. International Research Journal of Management, IT and Social Sciences, 6(6), 188-193. https://doi.org/10.21744/irjmis.v6n6.790 


\subsection{Effect of system quality on the SIPKD Use}

The results show that the quality of the system has a positive effect on the use of SIPKD in BPKAD Sikka Regency so that the third hypothesis (H3) is accepted. The implementation of SIPKD in BPKAD Sikka District shows that SIPKD is easy to use, has high access speed, is flexible for users in managing regional finances, and user data is safeguarded. SIPKD ease of use wherever and whenever the user wants to access the system.

The results of this study are in line with, Salim (2014), analysis of the success of the Senayan library information system with the DeLone and McLean model approaches at SMK Muhammadiyah 3 Yogyakarta. The results of this study indicate that the quality of the system of the Senayan library information system is good enough in accordance with student needs so that it is positively related to the level of use of the system by students.

The results of this study support the Theory of Reasoned Action which proves the decision made by individuals to accept a system is a conscious action that can be explained and predicted by their behavior. Whereas based on the DeLone and McLean model, it is proven that the quality of the information system is felt by the user of the system, both energy and time to complete the work.

\subsection{Effects of SIPKD Use on Individual Performance}

The results show that the use of SIPKD has a positive effect on individual performance in BPKAD in Sikka Regency so that the fourth hypothesis (H4) is accepted. The high level of use of SIPKD in BPKAD Sikka District can improve the performance or productivity of employees in these agencies. With the high use of the SIPKD, it can have an impact on improving the performance of employees such as the speed of carrying out tasks, facilitating the realization of work missions and achieving the work objectives of employees in BPKAD Sikka Regency.

The results of this study are in line with Kesumman \& Suardikha (2016), the use of the Regional Financial Management Information System on employee performance in regional work units. The results of this study indicate that the use of information systems has a positive effect on employee performance. This means that SKPD employees in the Denpasar City Government have been using SIPKD both routinely and a high level of use in completing their work.

The results of this study support the Theory of Reasoned Action which proves the use of an information system can have a positive impact on individual performance. By utilizing a system properly by individuals, it will help in completing existing work. Meanwhile, based on the DeLone and McLean models, it is proven that the use of a high system will accelerate the completion of work that is balanced with the ease of using SIPKD.

\section{Conclusion}

The results of the analysis of this study are that the quality of collaboration has a positive effect on the SIPKD use, this shows that the better the quality of collaboration, the use of SIPKD is increasing. The quality of information has a positive effect on the use of SIPKD, this shows that the better the quality of information produced from SIPKD, the use of SIPKD will increase. The quality of the system has a positive effect on the use of SIPKD, this shows that the better the quality of SIPKD, the use of SIPKD is increasing. The use of SIPKD has a positive effect on individual performance, this shows that the better the use of SIPKD, the performance of individuals is increasing.

\section{Conflict of interest statement}

The authors declared that they have no competing interests.

\section{Statement of authorship}

The authors have a responsibility for the conception and design of the study. The authors have approved the final article.

\section{Acknowledgments}

The authors would like to thank the reviewer for their consideration of the further process of the present paper. Thanks to the editor of IRJMIS for the valuable support, time as well as advice. 


\section{References}

Arauz, W. M. S., Gamez, M. R., Perez, A. V., \& Fernandez, M. C. (2016). Microgrids views from a geographic information system. International Research Journal of Engineering, IT \& Scientific Research, 2(11), 57-65.

Bhatti, Z. A., Baile, S., \& Yasin, H. M. (2018). Assessing enterprise wiki success from the perspective of end-users: an empirical approach. Behaviour \& Information Technology, 37(12), 1177-1193. https://doi.org/10.1080/0144929X.2018.1488992

DeLone, W. H., \& McLean, E. R. (1992). Information systems success: The quest for the dependent variable. Information systems research, 3(1), 60-95. https://doi.org/10.1287/isre.3.1.60

Delone, W. H., \& McLean, E. R. (2003). The DeLone and McLean model of information systems success: a ten-year update. Journal of management information systems, $19(4)$, 9-30. https://doi.org/10.1080/07421222.2003.11045748

Dewi, I. G. A. A. O., Dewi, I. G. A. A. P., Kustina, K. T., \& Prena, G. D. (2018). Culture of tri hita karana on ease of use perception and use of accounting information system. International Journal of Social Sciences and Humanities, 2(2), 77-86.

Fishbein, M. (1981). leek Ajzen (1975), Belief, Attitude, Intention, and Behavior: An Introduction to Theory and Research. Read-ing, MA: Addison-Wesley.

Hartono, S. R. (2007). Hukum Ekonomi Indonesia. Bayumedia Pub.

He, W., \& Yang, L. (2016). Using wikis in team collaboration: A media capability perspective. Information \& Management, 53(7), 846-856. https://doi.org/10.1016/j.im.2016.06.009

Hudin, J. M., \& Riana, D. (2016). Kajian Keberhasilan Penggunaan Sistem Informasi Accurate Dengan Menggunakan Model Kesuksesan Sistem Informasi Delon Dan Mclean. Jurnal Sistem Informasi, 12(1), 1-8. http://dx.doi.org/10.21609/jsi.v12i1.444

Humas MENPANRB. 2019. Siapkan generasi Smart ASN Hadapi Era Digitalisasi.

Jogiyanto, H. M. (2007). Model kesuksesan sistem teknologi informasi. Yogyakarta: Penerbit Andi.

Kesumman, P. M., \& Suardikha, I. M. S. (2016). Penggunaan Sistem Informasi Pengelolaan Keuangan Daerah Terhadap Kinerja Pegawai pada Satuan Kerja Perangkat Daerah. E-Jurnal Akuntansi, 1115-1144.

McCoy, S., Galletta, D. F., \& King, W. R. (2007). Applying TAM across cultures: the need for caution. European Journal of Information Systems, 16(1), 81-90. https://doi.org/10.1057/palgrave.ejis.3000659

Peraturan Bupati Sikka Nomor 49 Tahun 2016 Tanggal 15 Desember 2016 Tentang Kedudukan, Susunan Organisasi, Tugas dan Fungsi Serta Tata Kerja Badan Pengelolaan Keuangan dan Aset Daerah

PP No. 56 Tahun 2005 tentang Sistem Informasi Keuangan Daerah.

Pratolo, S., \& Jatmiko, B. (2017). Akuntansi Manajemen Pemerintah Daerah.

Salim, M. I. (2014). Analisis Kesuksesan Sistem Informasi Perpustakaan Senayan dengan Pendekatan Model DeLone dan McLean di SMK Muhammadiyah 3 Yogyakarta. Universitas Negeri Yogyakarta.

Tan, X. H., Liu, J. Y., Li, X. P., Zhang, L. H., \& Cai, J. (2015). A simulation method for permeability of porous media based on multiple fractal model. International Journal of Engineering Science, 95, 76-84.

Yasa, I. W. E. S., \& Ariyanto, D. (2017). Analisis kesuksesan sistem informasi manajemen daerah dengan mengadopsi model delone \& mclean. E-Jurnal Akuntansi, 2505-2533.

Jaeng, W. M. Y., Suardikha, I. M. S., \& Budiasih, I. G. A. N. (2019). Effect of use of regional financial management information systems on individual performance in BPKAD Sikka Regency. International Research Journal of Management, IT and Social Sciences, 6(6), 188-193. https://doi.org/10.21744/irjmis.v6n6.790 